\title{
MEMORIA E HISTORIA: DEBATES EN TORNO AL SIGNIFICADO DE LA INDEPENDENCIA EN MÉXICO (1821-1867)
}

\author{
MEMORY AND HISTORY: \\ DEBATES AROUND THE MEANING OF INDEPENDENCE \\ IN MEXICO (1821-1867)
}

\author{
Tomás Pérez Vejo \\ ENAH-INAH \\ perezvejo@gmail.com
}

\begin{abstract}
In this work, we analyzed the construction of a shared memory about the so-called Mexican War of Independence stemming from the debates in the press and the commemorative speeches of September 16 and 27 on the meaning and significance of what happened between the 1810 Grito de Dolores, and the 1821. Act of Independence of the Mexican Empire. We hypothesize that these dissensions have less to do with history than with memory and that they are an expression of two alternative nation projects, whose confrontation is one of the keys to the political life of the first independent Mexico.
\end{abstract}

Keywords: Political history, Mexico, 19th century, national construction, war of independence.

\section{Resumen}

El artículo analiza el proceso de construcción de una memoria compartida sobre la llamada Guerra de Independencia a partir de los debates en la prensa y los discursos conmemorativos del 16 y el 27 de septiembre sobre el sentido y significado de lo ocurrido entre 1810 y 1821. La hipótesis es que las disensiones no tuvieron que ver tanto con la historia como con la memoria, expresión de dos proyectos de nación, cuyo enfrentamiento fue una de las claves de la vida política del primer México independiente.

Palabras clave: Historia política, México, siglo XIX, construcción nacional, guerra de Independencia. 


\section{Introducción: el planteamiento de un problema}

La construcción de una memoria compartida sobre los hechos que habían llevado al nacimiento del nuevo Estado-nación mexicano resultó compleja y llena de matices. La historia de lo ocurrido entre 1810, Grito de Dolores, y 1821, Acta de Independencia del Imperio Mexicano, se imaginó y narró desde muy pronto como la Guerra de Independencia, que puso fin al dominio español sobre México, y la Revolución, que hizo lo mismo con el Antiguo régimen. A nadie se le ocultaba, sin embargo, con muchos de los protagonistas todavía vivos, el componente de guerra civil de lo ocurrido, que algunos de ellos siguieron afirmando hasta fechas muy tardías, "la revolución de 1810 siguió el rumbo de las guerras civiles, la adoptaron unos y la contrariaron otros [...] si el gobierno virreinal no hubiera contado con el apoyo de los naturales hubiera caído" (Tornel, 1849d: 1).

No fue una guerra de independencia de mexicanos contra españoles sino una guerra civil entre novohispanos. La mayoría de los combatientes, tanto del lado realista como del insurgente y entre los oficiales como entre los soldados, había nacido en el territorio de lo que después sería México y no de lo que después sería España, una guerra civil en la que, para complicar todavía más las cosas, resultaba difícil determinar cuál había sido el campo de la revolución y cuál el de la reacción. Los ejércitos realistas habían defendido alternativamente la revolución durante la vigencia de la Constitución de Cádiz y la reacción, después de la restauración absolutista de Fernando VII y el liberalismo de muchos de los líderes insurgentes, era poco discutible (Pérez Vejo, 2010, 2011 y 2017).

Algo tampoco nada excepcional, sólo las habituales dificultades para la construcción de una memoria compartida, con los vencedores buscando erigirse en albaceas de la memoria del conjunto de la comunidad política, pero teniendo que enfrentarse a la presencia de memorias personales y familiares distintas de las que el Estado busca convertir en verdadera. Para la memoria construida por el Estado nacido de la guerra civil novohispana, Hidalgo era el iniciador del proceso que había permitido a la nación mexicana recuperar su libertad e Iturbide su consumador, culminando en 1821 la obra iniciada en 1810. Sin embargo, en las personales y familiares de muchos mexicanos, el héroe de Dolores era el responsable de las matanzas y destrucciones llevadas a cabo por su ejército, "las hordas de Hidalgo", en los pueblos y ciudades del Bajío, y el de Iguala, el militar realista cuyas tropas habían diezmado, en el sentido literal del fusilamiento de una décima parte de su población masculina, a decenas de pueblos del propio Bajío.

Un conflicto resuelto, de manera general, es un genocidio de memorias. Los vencedores imponen un relato normalizado sobre el pasado, cuyo objetivo, obviamente no explícito, es lograr que la guerra pierda su carácter de conflicto civil y pase a nombrarse y recordarse como una guerra de independencia o una revolución (Ranzato, 1994). No una lucha entre hermanos sino un enfrentamiento, en el caso de la guerra civil, entre ellos, los ajenos y extraños a la nación, y nosotros, los que formamos parte de la fratría nacional; en el de la revolución, entre caducas minorías aferradas a la defensa de irracionales privilegios y la mayoría de la población portadora de la llama del progreso y la libertad. Reescritura del pasado en el que los vencidos pierden la guerra y, lo que es todavía importante, la legitimidad del discurso. Arrojados literal y metafóricamente al basurero de la historia.

La construcción de una memoria compartida y normalizada -en el caso de la guerra civil novohispana- tenía la dificultad añadida de que los vencedores, a pesar de que sus consecuencias más visibles habían sido la independencia y la revolución, parecían haber sido más los realistas, defensores del antiguo régimen y la unidad de la monarquía, que los insurgentes, defensores del fin de uno y otra. Los realistas encabezados por Iturbide no sólo fueron los protagonistas de la proclamación de la independencia sino también de la posterior vida política del Estado nacido de ella. Si, de manera gene- 
ral, los vencedores de cualquier guerra de independencia/revolución monopolizan el poder político, en el primer México independiente haber hecho la guerra con los realistas no fue impedimento para ocupar ningún cargo, ni siquiera los más altos, como refleja la sucesión de oficiales del antiguo Ejército del Rey llegados a la máxima jefatura del Estado: Agustín de Iturbide, Anastasio Bustamante, Manuel Gómez Pedraza, Antonio López de Santa Anna, José Joaquín Herrera, Mariano Paredes Arrillaga, José Mariano Salas, Mariano Arista, etcétera. Haber sido oficial realista casi parece más una condición que un obstáculo.

Contradicciones que explican la intensidad y sutileza de los debates en torno a la historia, pero sobre todo a la memoria, que se van a prolongar hasta entrada ya la segunda mitad del siglo cuando, desaparecidos ya la mayoría de los protagonistas y derrotado el proyecto conservador de nación, el nuevo Estado liberal pudo por fin imponer su versión oficial sobre el sentido y significado de lo ocurrido entre 1810 y 1821. Conflicto de memorias, que es la hipótesis central de este trabajo, expresión de otro de calado político-ideológico más profundo, de carácter identitario, sobre lo que México era, con la presencia de dos proyectos de nación a los que para simplificar voy a denominar liberal y conservador. Aunque, con la precisión necesaria, hacen referencia a un conflicto ideológico, derechos y organización social, no identitario, que somos. Como consecuencia, las líneas de fractura entre uno y otro no siempre son coincidentes.

En un conflicto de nación, como todos los de carácter identitario, la interpretación del pasado jugó un papel determinante, con dos interpretaciones sobre la historia de México, en realidad dos visiones sobre lo que México era, que en el caso de los conservadores encontró expresión en la metáfora del hijo que llegado a la edad adulta se emancipaba de la tutela paterna para iniciar su vida independiente: una nación mexicana nacida con la conquista, crecida en la época virreinal y llegada a la edad adulta con la independencia; y en el de los liberales, en un ciclo de na- cimiento muerte y resurrección: una nación mexicana nacida en la época prehispánica, muerta con la Conquista y resucitada con la Independencia.

Dos proyectos antitéticos e incompatibles, cada uno con su propia interpretación de la guerra de independencia, la continuidad de la Conquista para los conservadores, su venganza para los liberales; su propio padre de la patria, Hidalgo para los liberales e Iturbide para los conservadores; y su propia fecha de celebración de la Independencia, Grito de Dolores para los liberales, "nuestro homenaje de entusiasmo y gratitud [...] al inmortal sacerdote que lanzó el grito de Independencia, al día feliz en que su voz santa la proclamó [...] nuestro bello día es el diez y seis de Setiembre [sic]" (El Monitor Republicano, 1850a: 3), entrada del Ejercito Trigarante en la ciudad de México para los conservadores: "Si todas las naciones modernas tienen un día grande y glorioso de justo y noble orgullo y de inmortales recuerdos, este día para nosotros es el VEINTISIETE DE SEPTIEMBRE" (El Universal, 1849a: 1).

Los ingredientes de una interminable polémica histórico-política, que tuvo por escenario los más diversos campos de creación y difusión de ideas pero que encontró sus mejores expresiones en centenares de artículos en revistas y periódicos y, sobre todo, en los discursos pronunciados con motivo de las conmemoraciones de la Independencia, verdaderas clases de historia en las que año tras año se narró e interpretó lo ocurrido entre 1810 y 1821 como parte de un relato cuyos protagonistas no eran tanto los mexicanos como la nación mexicana. Dos veces por año ya que en el México del periodo aquí analizado existieron dos celebraciones de la Independencia -el Grito de Dolores (16 de septiembre) y la entrada del Ejército Trigarante en la Ciudad de México (27 de septiembre)-, que dada su cercanía temporal fueron origen a su vez de interminables polémicas en la prensa sobre lo dicho en cada uno de los discursos, incluida la habitual reproducción de los pronunciados en las ciudades más importantes en periódicos, revistas y libros. 
Los puntos de disenso entre uno y otro relato eran múltiples. No se limitaban al protagonismo de Hidalgo e Iturbide, un asunto hasta cierto punto anecdótico, sino que tenían que ver con dos interpretaciones sobre lo que México era que, por lo que se refiere a la Independencia, tendió a articularse en torno a tres temas claves: quienes habían hecho la Independencia, los descendientes de los conquistados o los de los conquistadores; la oportunidad de ésta en el momento en el que se había llevado a cabo, que llevaba implícita la de si México estaba maduro para iniciar su andadura como nación soberana o había sido un hecho prematuro; y los motivos que habían impulsado a los insurgentes a iniciar un conflicto tan sangriento como destructivo.

El primero, el de si la independencia había sido obra de los descendientes de los conquistadores o de los conquistados, que puede parecer el más retórico, tenía sin embargo un profundo calado político-identitario. Se trataba de decidir si la nación mexicana era heredera y continuadora del mundo prehispánico, el eje del proyecto de nación liberal, o por el contrario hija de la Conquista y del mundo virreinal, eje del conservador. Una pregunta a la que ya desde el mismo momento de la consumación de la Independencia se le había dado dos respuestas diferentes e incompatibles, la del Plan de Iguala, con su afirmación de que "Trescientos años hace, la América Septentrional, que está bajo la tutela de la nación más católica, heroica y magnánima. La España la educó y engrandeció formando esas ciudades opulentas, esos pueblos hermosos, esas provincias y reinos dilatados", con la nación mexicana como hija y continuadora de la española; y la del Acta de Independencia del Imperio Mexicano, de apenas siete meses después, consecuencia y continuación de aquel, con la de que "La Nación Mexicana que, por trescientos años, ni ha tenido voluntad propia, ni libre uso de la voz, sale hoy de la opresión en que ha vivido", con una nación mexicana preexistente a la Conquista que recobraba su libertad después de trescientos años de injusto sometimiento a la española.
Una pregunta, la de quiénes habían sido los autores de la Independencia, a la que los conservadores respondían que "los hijos de los que habían sacudido el ominoso yugo sarraceno, los hijos de los que habían hecho flamear en las torres de la Alhambra las enseñas de Castilla sobre la vencida media luna". Para que no quedase ninguna duda sobre lo que esto significaba, el autor de esta frase, González Bocanegra, el autor de la letra del himno nacional mexicano, concluye que se niega a "encontrar la causa de nuestra emancipación en el odio a la raza española [...] yo no puedo creer que sus corazones abrigaran una pasión ruin contra sus propios padres" (González Bocanegra, 1854: 1). No "era la nación conquistada, sino otra enteramente nueva" (El Pájaro Verde, 1865b: 2) la que se había levantado en 1810, hija de la española y no del mundo prehispánico.

Ésta no era la visión de los liberales para quienes la Independencia habría sido la venganza de la Conquista y de los tres siglos de explotación virreinal, con los indios primero como victimas y luego vengadores:

\begin{abstract}
A la sola voz de independencia, se enardecía súbitamente en todos los espíritus la memoria, siempre viva, de las atrocidades de la conquista; la memoria de tres siglos de vejaciones e injusticias, de tres siglos de humillación de la raza india, de tres siglos de privación de tantos bienes que la civilización podía haber derramado en México (Rosa, 1846a: 3).
\end{abstract}

La venganza de los descendientes de Cuauhtémoc y Moctezuma que caía sobre los descendientes de Cortés y de Alvarado. Algo que la retórica de Carlos María de Bustamante había afirmado desde muy pronto y que oradores y publicistas seguirán repitiendo en discursos y artículos de periódicos. La Independencia como la violenta convulsión que había permitido "sacudir el yugo opresor que nos impusiera Cortés" (El Monitor Republicano, 1857: 1). La nación mexicana que había sido esclavizada por los conquistadores en los inicios del siglo XVI volvía a ser libre trescientos años después. 
El segundo aspecto, el de la oportunidad de la Independencia, fue, a diferencia del anterior, un debate relativamente tardío. El sentimiento de que la nación no estaba todavía preparada para la Independencia y que lo ocurrido en 1810 había sido una rebelión caótica, sin objetivos definidos y bajo la dirección de unos caudillos incapaces -a quienes se hacia responsables de las atrocidades y estragos que el país había sufrido-, comienza a ser visible a comienzos de la década de los cuarenta, pero sólo adquirió presencia pública con la invasión norteamericana de 1847, cuando, visto desde la perspectiva que daba la bandera norteamericana ondeando en los balcones del antiguo palacio de los virreyes, el resultado más visible de la Independencia parecía ser la perdida de la mitad del territorio nacional y una sociedad en completa bancarrota social y moral. ${ }^{1}$ Era hora de preguntarse: ¿qué hemos ganado con la Independencia?

antes a lo menos prosperábamos, teníamos paz, riqueza, respetabilidad, todos éramos felices [...] Cuando vemos el miserable estado a que hemos venido; cuando a su sombra nos encontramos hoy, desmembrado el territorio, amagados de nuevas desmembraciones, quizás de perder la nacionalidad, en continua revuelta en el interior, agobiados por la miseria más espantosa, sin consuelo en lo presente, sin esperanza para el porvenir [...] ¿Qué hemos ganado con la independencia? (El Correo, 1851a: 1).

La respuesta a este ¿qué hemos ganado?, a partir de los presupuestos desde los que se plantea, era más que obvia: nada. Para El Correo la Independencia había resultado un fracaso y había llegado la hora de preguntarse si no también un error.

Un año después, con motivo de la celebración del 16 de septiembre, otro periódico conservador, El Ómnibus, es todavía más explícito: "¿es este día de júbilo o de duelo? el programa de las funciones que en

1 Sobre el sentimiento de crisis en las élites mexicanas después de la derrota de 1847 y sus diferentes respuestas véanse Hale (1990) y Suárez Argüello (1994). él se celebran, indican lo primero; mas la situación tristísima y verdaderamente desesperada de la República, anuncia lo segundo" (El Ómnibus, 1852: 1). Nada había que celebrar en una efeméride que año tras año marcaba un escalón más en la decadencia de la nación. La larga y sangrienta lucha por la independencia y las desgracias que había traído consigo se habían justificado por los bienes futuros, pero ¿dónde estaban estos bienes? El panorama no podía ser más desolador, el comercio paralizado, la agricultura estancada, la industria sin futuro, la sociedad sin orden y sin leyes, el Estado sin hacienda, sin crédito y sin ejército y las fronteras amenazadas por los indios bárbaros y por las ambiciones de los Estados Unidos. Era el momento de preguntarse

¿de que le sirvió [a México] haber conquistado su independencia? ¿La adquirió sólo para usar mal de ella, y perderla al punto vergonzosamente? ¿Se substrajo de la autoridad paterna, bajo la cual se le trataba como a hijo (e hijo muy considerado) para pasar al dominio de un nuevo Señor que lo tratará como esclavo? (El Ómnibus, 1852: 2).

No se ponía en cuestión la necesidad de la independencia, pero sí la oportunidad del momento en que se hizo. El error de una independencia prematura en un país que todavía no estaba preparado para ella y cuyas consecuencias la nueva nación estaría todavía pagando.

La respuesta liberal tomó dos caminos distintos: negar que el país no estuviese maduro para la independencia y afirmar que, dado que la mayoría de los defectos de la nueva nación tenían su origen en la herencia española, de nada hubiese servido prolongar una presencia que lejos de corregirlos los habría acentuado. Sobre lo primero, al margen de que resultaba difícil determinar en qué consistía estar maduro para la independencia, de lo que no cabía ninguna duda era que en el momento en que ésta se produjo la nación mexicana estaba, al menos, tan preparada como la nación española para una vida independiente, "en 1810 
la clase media y las clases más elevadas de México estaban tanto o más civilizadas que las mismas clases en España" y el pueblo estaba igual de atrasado a uno y otro lado del Atlántico. La única diferencia era la situación del indígena, "en el último grado de ignorancia, de abyección y de miseria”, pero esto era el resultado, y aquí pasaríamos al segundo aspecto, de cerca de tres siglos de humillación y explotación, por lo que de nada hubiese servido prolongar una forma de gobierno que era el problema y no la solución. Y, además, el indígena era "por el odio implacable con que justamente veía a sus opresores" (Rosa, 1846a: 3) la que mejor preparada estaba para la independencia.

El rechazo de la prensa liberal a los argumentos de la conservadora sobre la oportunidad o no de la independencia es radical y sin matices, pero el sentimiento de crisis y desencanto debió de ser suficientemente intenso en algunos momentos de los inicios de la década de los 50 como para que incluso los propios liberales acabasen justificando la independencia no por sus resultados sino por el valor de los hombres que la habían llevado a cabo:

Nuestra independencia tiene sus mártires que la sancionaron con su muerte en los campos de batalla, y con los sufrimientos inexplicables de una muerte en el Cadalso. Nuestra independencia, en fin, fue proclamada de una manera heroica, que quizás no tiene ejemplo. Y en verdad, que lo que de tan noble modo comienza no puede nunca ser un mal menor (El Siglo XIX, 1851: 1).

Quizás la diferencia estaba en que para los liberales, que asumían la existencia de una nación mexicana que nada tenía que ver con España, la independencia era un bien en sí mismo. Los conservadores, quienes creían que México había nacido de la Conquista y para los que no existía México sin España, la independencia era sólo una alternativa, no un bien en sí. El tercer aspecto, el de los motivos para la Independencia, afectaba casi exclusivamente a los conservadores. Para los liberales, la opresión y discriminación es- pañola sobre indios y criollos había sido de tal magnitud que lo único que cabía preguntarse era el porqué no se había producido antes. Había sido la opresión política, social y religiosa de España la causa y el origen de la emancipación. Para los conservadores, que negaban tanto la explotación de los indígenas como la marginación del crioIlo, "Ilamado por la ley a ocupar los mismos puestos que sus padres, con las prerrogativas del vencedor de quien descendía, era legalmente igual a los señores del país" ( $E /$ Universal, 1854a: 1), afirmar que la opresión española había sido el origen del movimiento insurgente era sólo una muestra de ignorancia histórica.

Pero si en el origen del movimiento insurgente no estaban la opresión y la explotación españolas, cómo explicar y justificar una independencia que no sólo había tenido lugar, sino que, además, se consideraba positiva y necesaria. Los motivos tenían que ver con la distancia, que había hecho que una misma raza trasplantada a un suelo distinto hubiera acabado por adquirir costumbres, peculiaridades y gustos distintos a los de la raza de origen. La convivencia se había ido haciendo cada vez más y más difícil. Las leyes comunes cada vez eran menos adecuadas a las necesidades de la nueva sociedad y cada vez se sentía más la necesidad de un gobierno cercano y propio. Las causas de una guerra de independencia que, quizás, podría haberse evitado si los monarcas españoles no hubiesen cerrado sus oídos a los sagaces consejos del conde de Aranda y su proyecto de dividir América en reinos independientes bajo el gobierno de personas de la familia real. Hubiera sido, según esta visión, posible y deseable una independencia pactada, de separación amistosa, en la que las dos ramas de una misma familia habrían seguido cada una su camino sin necesidad de los sangrientos y desastrosos episodios de una guerra entre hermanos cuyas consecuencias todos estaban todavía pagando.

Hubo otra explicación, ideológicamente más insidiosa, que justificó la Independencia por la incapacidad de la propia España para mantenerse fiel a los dos elementos que his- 
tóricamente habían definido su civilización: el trono y altar. Ambos habían sufrido sus primeros ataques de parte de las cortes gaditanas y los españoles americanos "entusiastas por el decoro de la autoridad real" $\mathrm{y}$ "celosos en todo lo concerniente a la religión" (El Universal, 1854b: 1) entendieron que nada podían esperar de la Península por lo que decidieron romper sus lazos con ella. El objetivo que los empujaba había sido cerrar el paso a la Constitución de Cádiz, que "contenía el germen de un desorden completo en todos los ramos" (Diario de Avisos, 1859: 1). Argumento de una cierta sofisticación intelectual ya que no sólo permitía una explicación histórica con visos de verosimilitud, al fin y al cabo la Proclamación de la Independencia había coincidido con la reimplantación del régimen liberal en la metrópoli y el Plan de Iguala podía verse como una negativa a aceptar la Constitución de 1812, sino que además, de paso, hacía aquella obra de los conservadores y de su héroe, Iturbide, frente al denostado Hidalgo y explicaba los males de la nación por el hecho de no haber sabido mantenerse fiel a los principios moderados proclamados en Iguala. Tenía además a su favor el hecho de que tanto liberales como conservadores asumían, en líneas generales, el carácter precursor que la Constitución de Cádiz había tenido en la difusión de las ideas liberales, e incluso republicanas, en América:

trabajando por el engrandecimiento de su patria [los diputados gaditanos] trabajaban al mismo tiempo por el establecimiento de una constitución republicana en las colonias; porque exceptuando la sucesión hereditaria, y la aparente inviolabilidad de los monarcas, todo era republicano, todo era democrático, todo era popular en los principios que sostenían y propagaban en España los constitucionales (Rosa, 1846b: 3).

Tampoco era tan inverosímil considerar que lo que realmente habían buscado los autores de la Independencia en 1821 era evitar el contagio gaditano, y más después de la rebelión de Riego. Incluso alguien como
Tornel, sobre cuya adscripción liberal no había ninguna duda, se hizo eco de ella en una de sus polémicas periodísticas sobre la Independencia. Cuenta cómo habiendo sido destinado con otros oficiales para cumplimentar a O’Donoju a su llegada a Veracruz, éste "me manifestó serios temores de que la revolución tomará un camino anti-liberal, y me preguntó si era cierto el hecho de que la Inquisición se había restablecido en Guanajuato". Temores, a decir del propio Tornel, nada infundados "examinando los antecedentes y la clase de personas, que [...] promovían la emancipación de México con mayor empeño" (Tornel, 1850: 1).

Estos tres aspectos digamos teóricos se van a plasmar en el análisis concreto de la comparación entre el México del periodo virreinal y el de la época independiente y de un juicio moral sobre la forma en que la Independencia había sido llevada a cabo. Como telón de fondo la polémica sobre sí, como mantenían los conservadores, el error no había sido dar al país una organización en desacuerdo con las "costumbres, creencias, intereses y necesidades del pueblo" (El Correo, 1851a: 1).

Una interminable polémica histórico-política, de la que por motivos de espacio no me voy a ocupar aquí en toda su riqueza, sino que me voy a centrar sólo en la forma como Hidalgo e Iturbide fueron utilizados en ella. No como personajes reales sino como bandera de estos dos proyectos alternativos de nación. El objetivo no es dilucidar el ahistórico problema de quién es el héroe o el villano. Pocos son los padres de la patria, de no importa qué patria, que saldrían indemnes de un juicio de este tipo, todos con más posibilidades de ser declarados criminales de guerra que benefactores de la humanidad, sino entender el proceso que convirtió a uno y otro en expresión de cada uno de estos proyectos de nación.

Con la precisión necesaria de que el que uno, Hidalgo, acabase como símbolo del proyecto de nación liberal, y otro, Iturbide del conservador, nada tiene que ver con los posicionamientos político-ideológicos de uno y otro. Tan liberal, en realidad tan poco, 
había sido el héroe de Dolores como el de Iguala.

\section{Iturbide e Hidalgo frente al tribunal de la Independencia}

El debate sobre la Independencia no afecta sólo a su saldo final sino también al valor e integridad moral de los hombres que la llevaron a cabo y quien debía de ser considerado el verdadero autor de ella, con dos posibles padres de la Independencia, Hidalgo como iniciador e Iturbide como consumador, y hasta aquí no había problema; que habían militado en campos distintos, uno en el realistas y otro en el insurgente, y esto volvía ya su memoria mucho más conflictiva; y que el debate político decimonónico convirtió en símbolo de dos proyectos de Estado y de nación antagónicos, y aquí el conflicto se volvía prácticamente irresoluble, la conversión del uno en héroe conllevaba la del otro en villano y viceversa.

Tuvo su plasmación simbólica en la polémica sobre qué día se debía celebrar la Independencia, el 16 de septiembre (Hidalgo) o el 27 de septiembre (Iturbide), iniciada casi desde el momento mismo de su proclamación. El Congreso Constituyente debatió en los primeros meses de 1822 sobre cuál de los dos días debía de ser declarado festivo $y$, después de una ríspida discusión, se optó por incluir ambos (Decreto del 1 de marzo de 1822). Puede resultar extraño que en momentos tan complicados para el país, recién declarada la Independencia, se perdiese el tiempo en asuntos tan aparentemente banales, pero, como supo ver ya Alamán, lo que estaba detrás era el no resuelto enfrentamiento entre los antiguos insurgentes y los partidarios de Iturbide, reactualizado como una discusión entre defensores de la monarquía y de la república:

Al desprevenido que lea las actas [...] podrá parecerle frívolo el gasto de tiempo en asunto tan trivial [el de las fechas que debían de ser declaradas festivas] y pensará que habría sido mejor emplearlo en ventilar la gran cuestión para la cual fue convocado el Congreso [defi- nir el sistema de gobierno]. Pero la verdad es que no otra cosa se discutía, porque un voto a favor de la memoria de Hidalgo había adquirido el sentido de un voto republicano (cit. en Garrido Asperó, 2006: 155).

Yo añadiría que no se estaba debatiendo sólo sobre monarquía o república, dos proyectos alternativos de Estado, sino también sobre dos comunidades imaginadas posibles, dos proyectos alternativos de nación. Para los defensores del proyecto de nación conservador el auténtico padre de la patria había sido Iturbide, "un guerrero mexicano, que había militado como otros muchos bajo las banderas de España" (Anievas, 1854: 1). No sólo el consumador de una independencia hacía tiempo ya naufragada sino símbolo él mismo de la continuidad con España y el pasado español.

Los discursos cívicos del 27 de septiembre, en conmemoración de la entrada del Ejército Trigarante en la Ciudad de México, están llenos, en épocas de gobiernos conservadores, de hiperbólicas alabanzas al héroe de Iguala, a quien se le compara con personajes bíblicos y de quien se elogia desde su porte distinguido y majestuoso hasta su clarividencia política. Imagen que tenía su correspondencia en lo que podemos denominar una visión de consenso de la Independencia, resultado no de un rechazo de lo que la metrópoli era y representaba sino del crecimiento natural de la que podía considerarse su hija primogénita. La Independencia no se justificaba en la opresión española sino en que la Nueva España había llegado a un nivel de desarrollo que hizo innecesarios los antiguos lazos. Había sido la benéfica administración colonial la que había permitido crear las condiciones para que México pudiera ocupar su lugar entre las naciones del mundo. No era necesario negar a España para afirmar a México, "Iturbide [...] sin calumniar a la Nación-metrópoli, justificó plenamente la independencia de la Nación-colonia" (Martínez, 1853: 3).

Frente a Iturbide y el Plan de Iguala se alzaban, para los conservadores, las imágenes mucho más conflictivas de Hidalgo y el 
Grito de Dolores. Si los primeros representaban la voluntad de construir sobre la antigua tierra de Anáhuac, tal como había afirmado el propio padre de la Independencia en Iguala, una nación que incluyese "no sólo a los nacidos en América, sino a los europeos y asiáticos que en ella residen"; en los segundos estaban el germen de la desunión y las guerras civiles que habían ensangrentado y seguían ensangrentando el suelo de México. Había habido en Hidalgo un error de principios, justificar la independencia por la conquista y no por el desarrollo moral y social de la Nueva España, y de medios, usar la división y el enfrentamiento como arma de lucha política, dividir y no sumar. Resultaba sin embargo difícil un rechazo frontal de la figura de Hidalgo, al que en ningún caso se le podía negar ser el iniciador del proceso culminado por Iturbide. Contradicción que, de manera general, se resuelve encomiando el valor y el patriotismo del cura de Dolores, el arrojo de haber prendido la llama de la independencia, pero resaltando que se había equivocado "en los medios para obtenerla" por lo que lo único que había conseguido era "llenar el país de sangre, de luto y de miseria" (Vargas, 1859: 1).

El objetivo había sido noble pero la forma de lograrlo inicua y contraproducente. Más que de una continuidad entre la obra de Hidalgo y la de Iturbide habría que hablar de una negación en la que las desgracias originadas por el primero habrían sido corregidas por el segundo, "el pensamiento político de Iturbide, no sólo no fue el de Hidalgo, sino que ambos eran opuestos [...] nada tiene de extraño que quien combatió a los insurgentes en 1810, emancipase a México en 1820". La pasión política tergiversaba los hechos y se empeñaba en juntar lo que nada tenía en común, la sangrienta y estéril revuelta de Hidalgo con la independencia nacional. Iturbide había opuesto al odio de raza de Hidalgo la unión de "todos los habitantes de la Nueva España, sin distinción alguna de europeos, africanos ni indios", de forma que bajo la bandera de Iguala habían tenido cabida tanto "los jefes españoles $\mathrm{Ne}$ grete y Luaces" como "los antiguos insur- gentes Guerrero y Osorio" (Diario de Avisos, 1859: 1).

Para los liberales, por el contrario, la importancia de Hidalgo, ${ }^{2}$ así como su inteligencia, talla política y valor moral eran indiscutibles. Las oraciones cívicas del 16 de septiembre desgranan, con la cadencia de un rosario laico, sus virtudes, "el patriotismo ardiente, la abnegación de sí mismo, la constancia, el valor [...]” (J. J. C., 1845: 1). Una especie de héroe sin mácula que había triunfado en todo lo que se había propuesto, cuando quiso ser sabio, "fue sabio, pero la universidad le cerró sus puertas"; cuando quiso introducir la industria en México "los gusanos de seda le donaron sus regias vestiduras; pero el monopolio extranjero entregó a las llamas sus rivales"; cuando quiso ser agricultor "las viñas le sonreían desde los collados, pero la espada íbera decapitó los racimos" (Ramírez, 1861: 1); Hidalgo era el "padre" y el "amigo fiel", el que "trabajaba" y "sufría por vosotros [...] el ángel de vuestra guarda", el que "os animaba en medio de la acción y os exhortaba a la batalla”, el que "combatía por salvarnos y peleaba por nosotros" (Villalobos, 1850: 3). Un hombre sin igual que en un rincón perdido, sin apenas medios y con apenas el apoyo de un puñado de indios, había iniciado la titánica tarea de liberar a una nación de una de las monarquías más poderosas de la tierra, "un genio singular [...] un hombre sin igual" capaz de "dar principio de vida a un pueblo muerto" (Saavedra, 1850: 1).

Una especie de Dios laico, "Todos los pueblos han contado en el número de sus dioses a los hombres que les han prestado un servicio inminente" (Castillo Velasco, 1850: 1). El Moisés contemporáneo que, lo mismo que había hecho el bíblico con los israelitas guiándoles a la tierra prometida pero sin llegar a entrar en ella, habría guiado a los mexicanos dándoles la patria que no tenían. Aceptan, en el peor de los casos, "errores y algunos crímenes" en la revuelta del cura de Dolores, pero incluso éstos eran "hijos naturales de la educación enteramen-

\footnotetext{
2 Para la construcción de Hidalgo en el imaginario mexicano véase Herrejón Peredo (2000).
} 
te española que el pueblo había recibido" (Tornel, 1849c: 1). La Inquisición y la picota no eran precisamente cátedras de derecho de gentes e Hidalgo había tenido que apoyarse en un ejército de "indígenas miserables que no conocían el manejo de las armas [...] hombres ignorantes que pretendían librarse de las balas de cañón cubriéndose con sombreros" (Yslas, 1857: 1). Si durante un cierto tiempo las desgracias se habían abatido sobre una sociedad que luchaba por emanciparse de sus opresores la culpa no podía imputársele a Hidalgo ni de los demás caudillos insurgentes sino "a la misma naturaleza de las cosas, y a la resistencia del antiguo gobierno" (Garfias, 1855: 2). Las revoluciones se hacían con sangre y, como se preguntaba retóricamente Guillermo Prieto en su discurso del año 1861, "¿Qué hubiera sido de nuestra independencia, si en vista del participio feroz de tribus medio salvajes, si en presencia de ese sarcasmo de fanatismo y de venganza, escrito en el estandarte de Dolores, hubiera retrocedido Hidalgo?". No se podía culpar a Hidalgo por unos miles de cadáveres más o menos. La grandeza de su fin justificaba los puntuales errores que se hubiesen cometido para lograrlo, "la idea de Hidalgo era como esas fuentes poderosas que brotan en una cascada, se precipitan en un abismo, reaparecen [...] riegan o destruyen, fertilizan o aniquilan [...] hasta que toman al fin un curso sosegado y benéfico" (El Monitor Republicano, 1861: 2).

La estatura política de Hidalgo era muy superior, por todos los conceptos, a la de Iturbide que, finalmente, se habría limitado a llevar "a un término venturoso el movimiento del venerable párroco de Dolores" (El Monitor Republicano, 1850b: 3). Sin el primero nunca hubiese existido el segundo y a éste difícilmente se le podía perdonar su participación del lado de los españoles en la Guerra de la Independencia y la veleidad de haberse proclamado emperador. Pero, a diferencia de lo que ocurre con los conservadores que en momentos especialmente álgidos del conflicto identitario llegan a negar a Hidalgo un lugar entre los padres de la patria, la actitud de los liberales, al menos en las primeras décadas de vida independiente, es de un mayor consenso: Hidalgo es el padre de la patria pero con Iturbide conservando algún protagonismo. Nadie le podía negar su condición de padre de la independencia, "él más que nadie es el padre de nuestra independencia" (El Monitor Republicano, 1857: 1), y finalmente su abrazo con Guerrero había sido "el anillo que enlazó a Dolores con Iguala” (Yslas, 1857: 1).

Un mayor consenso relativo, que se esfumó derrotado el proyecto de nación conservador. El finalmente triunfante proyecto de nación liberal borró por completo a Iturbide del santoral laico de la patria. La fiesta nacional no es la conmemoración de la Proclamación de la Independencia sino la del Grito de Dolores, aunque en él nadie haya declarada independencia alguna, y ninguno de los estados de la República lleva el nombre de Iturbide, a diferencia de lo que ocurre con Hidalgo, Morelos o Guerrero. La propuesta de Miramón, 1858, de crear el territorio de Iturbide, con los distritos de Cuautla, Cuernavaca y Taxco, convertido con Maximiliano en el departamento de Iturbide, no sobrevivió a la caída del Imperio, siendo finalmente Morelos quien acabó dando nombre al Estado. La paradoja de que el autor material de la Independencia mexicana haya sido borrado por completo del santoral laico de la nación, más paradójico todavía si consideramos que estamos ante un calendario nacionalista especialmente rico, en el que se celebran desde el aniversario del natalicio de Juárez al de la nacionalización del petróleo. Una exclusión que, sin embargo, no es obra tanto del periodo aquí analizado como de la República Restaurada y el Porfiriato, con una versión mucho más sectaria del relato de nación sobre la independencia. Tendría su máxima expresión en el Monumento a la Independencia construido en 1910, bajo el gobierno de Porfirio Díaz, en el Paseo de Reforma de la ciudad de México en el que Iturbide no tuvo derecho ni siquiera a una estatua, y eso que entre los que tuvieron derecho a ella se incluyen personajes con tan poca relación con ella o tan pintorescos como el español Francisco Javier Mina o el 
irlandés Guillén de Lampart. Iturbide tampoco tuvo el derecho a que sus restos descansasen junto con los demás héroes en la base del monumento. El consumador de la Independencia es el único de los padres de la patria, cuyos huesos reposan en la catedral metropolitana, un último vestigio de la época virreinal que parte del México independiente.

La imagen liberal de Hidalgo tenía su correspondencia, simétricamente con el caso anterior, con lo que podemos denominar una visión de conflicto de la Independencia. Ésta no habría sido el resultado de ningún proceso de crecimiento natural sino, por un lado, del rechazo a la codicia y la opresión española que habían privado a México durante tres siglos de cualquier tipo de progreso y civilización; por otro, de la venganza de los mexicanos por lo que trescientos años antes les habían hecho los españoles.

Por lo que se refiere a lo primero, los trescientos años de presencia española en México podían resumirse en

trescientos años sin comunicación con el mundo, privado en ciencias y letras de aquella luz progresiva, que cada siglo a su vez iba por todas partes esparciendo con sus nuevos escritos, privado de los principios y descubrimientos, que día a día perfeccionaban la industria; privado aún del cultivo de las plantas que podían disminuir el gran consumo de cuanto introducían su opresores [...] excluidos [los mexicanos] de todos los empleos de primera orden [...] sujetos a la voz imperiosa y a la mirada despótica del que mandaba y del que no mandaba, con tal de que hubiera venido de más allá de los mares (Fernández Bustamante, 1845: 3).

Por lo que respecta a lo segundo, ya Carlos María de Bustamante había dejado asentado, muy pocos años después del Grito de Dolores, en el discurso que escribió para la apertura del Congreso de Chilpancingo por Morelos, que con éste los hijos y descendientes de Cuauhtémoc y Moctezuma habían sido vengados. Afirmación que los oradores liberales seguirán repitiendo los 16 de septiembre de cada año en discursos y oraciones cívicas a lo largo y ancho del país.

Planteamientos a partir de los que resultaba bastante evidente que el grito de Dolores no era la continuidad de nada sino la ruptura con un pasado ominoso y, si acaso, la vuelta a uno más antiguo y genuinamente mexicano. Contexto en el que las polémicas sobre el sentido y significado del grito de Dolores se volverán unas de las más recurrentes y conflictivas de las primeras décadas de vida independiente.

El juicio negativo sobre el grito de Dolores se había iniciado de hecho, con la propia proclama de la independencia. Recordemos que Iturbide habló en ella de la voz que resonó en Dolores "y que tantas desgracias originó al bello país de las delicias, por el desorden, el abandono y otra multitud de vicios". Palabras sobre cuyo significado último poco cabía discutir y que serán repetidas una y otra vez por oradores y articulistas conservadores. La Guerra de Independencia había sido especialmente cruel y sanguinaria y la cercanía de los hechos hacía difícil ocultarlas. Para los conservadores, el culpable de las atrocidades cometidas era Hidalgo, quien, carente de cualquier plan, había lanzado a sus hordas de desarrapados en contra todo lo que de honrado y decente había en la sociedad novohispana. Para los liberales, que tampoco negaban el carácter sanguinario de la contienda y sus altísimos costes, humanos y materiales, el responsable había sido el gobierno español que con su fanatismo había impedido "hacer la guerra, como se hace entre las naciones cultas y cristianas" dando a la Guerra de Independencia "un carácter de atrocidad y de devastación, que de otra manera no habría tenido". Lo que había habido de cruel e inhumano en ella no eran "sino las represalias que la barbarie del gobierno español hizo necesarias" (Rosa, 1846a: 3).

La polémica sobre el significado exacto del levantamiento de 1810 alcanzó su momento de mayor tensión a finales de 1849 cuando, coincidiendo con la celebración del 16 de septiembre, El Universal comenzó la publicación una serie de artículos en los que 
se minimizaba la aportación de Hidalgo al proceso independentista y se magnificaban los nocivos efectos de su participación. Artículos que coincidieron, desgraciada coincidencia según Tornel, "me permitirá que llame desgraciada la coincidencia de la aparición de sus Historia de México [se trata de una carta abierta dirigida a Alamán], con la de algunos artículos de El Universal, muy a propósito de sublevar las pasiones" (Tornel, 1849a: 1), con la publicación de la Historia de Méjico desde los primeros movimientos que prepararon su independencia en el año de 1808, hasta la época presente, en la que se mantenían tesis muy semejantes y a la que se citaba como principal fuente histórica. Dieron origen a una larga polémica, se prolongó durante todo el año siguiente, en la que participaron todos los periódicos liberales, desde los de mayor difusión, El Siglo XIX o El Monitor Republicano, hasta los más minoritarios, La Palanca o El Busca-Pies.

No era para menos. El Universa/ proponía una completa revisión histórica con el objetivo de "vindicar a nuestra historia de la injuria que [...] se le ha hecho, contando entre sus acontecimientos más gloriosos el grito de Dolores" y "quitar a la independencia de México, la mancha de haber tenido una cuna indigna de su nombre y gloria”. Había que desmontar la memoria sobre la independencia inventada por los liberales, una "mentira convencional, creada por el interés personal de algunos, tolerada por la pusilanimidad de muchos, y vista con indiferencia por la ignorante e imprevista multitud" (El Universal, 1849b: 1). Ni el grito de Dolores había sido lo que se había dicho ni su significado tenía nada que ver con lo que se decía. No se podía "celebrar el 16 de septiembre a los fusilados, y el 27 del mismo mes a los fusiladores". Una ofensa a los militares que con tanto denuedo y valor habían reprimido la barbarie de Hidalgo y sus seguidores salvando "el honor de un pueblo culto y humano" (El Universal, 1849c: 1). Iguala no era la culminación de Dolores sino, afortunadamente, su negación. No había continuidad histórica entre un hecho y otro. El primero marcaba el día glorioso en el que México había logra- do su independencia, el segundo un oscuro y triste episodio que sólo merecía el olvido y el desprecio.

Los argumentos de El Universal se resumían en que Hidalgo había obrado y citaba para dar más fuerza a su afirmación lo escrito por Lorenzo de Zavala en su Ensayo histórico de las revoluciones de México, desde 1800 a 1830, "sin plan, sin sistema y sin objeto determinado. Viva Nuestra Sra. de Guadalupe era su única base de operaciones". No se podía atribuir la Independencia a alguien que había obrado sin un plan determinado. Tampoco se podían comparar a "Washington, Franklin y Montgomery, que proclamaron la independencia de su patria con Hidalgo, Morelos y Matamoros que proclamaron la religión y los derechos de Fernando VII". Hidalgo no había iniciado la Independencia sino las matanzas que durante años ensangrentaron el suelo mexicano. La incitación a la matanza de españoles y al saqueo se había encontrado con la oposición unánime de "los buenos mexicanos [...] americanos y europeos". El partido de la insurrección era "tan abominable" que el partido del gobierno español, "aunque despótico", resultaba preferible.

El movimiento del cura de Dolores poco o nada tenía que ver con la Independencia. Había sido "una rebelión que no tenía objeto alguno social o político" (El Universal, 1849e: 1). Como no se podía considerar programas políticos a la defensa de una religión, la católica, y de unos derechos, los de Fernando VII, que nadie había atacado, lo único que quedaba era el iMueran los gachupines! Pero, ¿se podía considerar programa político "mueran nuestros padres, nuestros hermanos, nuestros parientes, nuestros vecinos [...] mueran todos los individuos que forman la porción más ilustrada, más moralizada, más trabajadora del país"? Evidentemente no, ese grito sólo expresaba "un odio injusto y un deseo bárbaro y atroz" (El Universal, 1849d: 1). Por eso los seguidores de Hidalgo, carentes de cualquier proyecto político, se habían limitado a recorrer el país, de matanza en matanza, de Guanajuato a Celaya, seguido por un informe tropel sin más ob- 
jetivo que la muerte de españoles y el saqueo. Había sido esta falta de programa y de garantías el que habría puesto a la gente decente del lado del gobierno español prolongando innecesariamente la lucha durante diez largos años. Si algún efecto había tenido la proclama de Hidalgo y sus acciones posteriores había sido el de retrasar y contrariar la Independencia. Todo lo que había de decente en la sociedad mexicana se vio empujado a cerrar filas contra los desmanes de Hidalgo y sus seguidores, incluso, como habría sido el caso de Iturbide, aunque en su interior fueran partidarios de la independencia.

La conclusión era obvia, ni Hidalgo había proclamado la independencia, ni ésta había sido en ningún momento su objetivo:

Si Hidalgo obraba sin plan, sin sistema y sin objeto determinado ¿cómo es que se le atribuye la gloria de haber proclamado la independencia? Si su grito fue un grito de muerte, y el primer paso de su carrera la señal de las matanzas que inundaros de sangre nuestro suelo ¿cómo se pretende que su causa haya sido la causa de la nación mexicana? Si no había orden, ni armonía, ni nada en aquella insurrección ¿cómo es posible que ella haya sido la expresión fiel de los sentimientos de un pueblo ilustrado? [...] Con razón, pues, se vio aislado y solo [...] y fue combatido por los buenos mexicanos que no podían menos de ver con horror los asesinatos y robos de los primeros insurgentes (El Universal, 1849e: 1).

Los buenos mexicanos habían tenido que elegir entre un partido, el de Hidalgo, "que atacaba horrorosamente la vida e intereses de todos los ciudadanos, trastornaba el orden público, y atropellaba todos los principios de moralidad y de justicia" y otro, el del gobierno español, que "ofrecía seguridad a las propiedades, y un orden regular y conocido".

Hidalgo no había proclamado nada ni podía considerarse glorioso ni heroico un hecho basado en la ignorancia, el crimen, el saqueo y el asesinato, "Guardad para vosotros esa gloria; la nación no la quiere: Ilevaos al héroe; la patria le desconoce".

Pero no era sólo un asunto de estrategia política, la catadura moral de Hidalgo le imposibilitaba para ocupar un lugar en altar de la patria, "sus primeros soldados son criminales sacados de la prisión", sus primeras víctimas "sus amigos" con los que "había pasado aquella noche hasta las once en amistosa tertulia". No se podía colocar a un asesino al lado de los héroes que habían hecho la independencia. Un "pueblo, noble, justo y generoso" no podía reconocer a alguien así, a un bandido, "como su libertador" (El Universal, 1849d: 1).

El ataque resultaba tan demoledor que El Monitor Republicano no encontró mejor argumento que desautorizar a Zavala y negar que Hidalgo hubiese nunca utilizado ni el viva Fernando VII ni el mueran los gachupines. El grito de Dolores habría sido viva la libertad, viva la virgen de Guadalupe, y muera el mal gobierno (El Monitor Republicano, 1849a: 3-4). El argumento resultaba tan arriesgado, finalmente la única fuente que habían encontrado para oponer a Zavala sobre lo que se había gritado en Dolores, que en realidad nadie sabía muy bien que había sido, era la de Blanco White, un español que nunca había estado en México, que dos días más tarde, tras un fracasado intento de la Cámara de Diputados de llevar a El Universal ante el jurado de imprenta, concluyó que a quien le importaba saber si Hidalgo había gritado viva Fernando VII o viva la Virgen de Guadalupe, lo único de que se trataba era de saber "si Hidalgo fue o no un hombre benéfico, patriota, enemigo de la dominación" y sobre esto no había ninguna duda, era "una verdad patente", sin necesidad de demostración alguna. Pocas veces se expresa de manera tan clara hasta que punto la historia fue en el siglo XIX un problema político y no historiográfico. Cuando no sirve para los objetivos propuestos simplemente se prescinde de ella, lo que importa son las intenciones y las ideas, "ataquemos sus ideas [las de El Universa/] por lo que pueden influir en el mal del país, y dejemos sus cuestiones necias y estériles [las precisiones historiográficas que había hecho a la versión 
de lo ocurrido en Dolores de El Monitor]" (El Monitor Republicano 1849b: 4), no la verdad o falsedad de los hechos históricos.

La polémica continuó con una larga respuesta de Tornel, publicada tanto en El Siglo XIX como en El Monitor Republicano, los dos principales periódicos liberales del momento. A Tornel no parece interesarle tanto responder a los redactores de El Universal, a quienes considera una continuación, en peor, del monárquico El Tiempo, sino la recién publicada primera parte de la Historia de Alamán, "ha aparecido una parte de cierta obra, escrita con decencia, recomendada de antemano por la elevada capacidad de su autor, rica en documentos [...] de estilo claro, ameno y fluido" (1849b: 2) por lo que, en un primer momento, se centra más en las afirmaciones de éste sobre la colonia que en los denuestos de El Universal sobre Hidalgo.

Ya posteriormente, y tras el rechazo de Alamán a seguir discutiendo hasta que no apareciese la segunda parte de su Historia, Tornel sí se ocupa de responder a El Universal, a cuyos redactores, después de acusarlos de españoles, ${ }^{3}$ reprocha el no considerar los hechos en su conjunto sino centrarse en episodios aislados de los que habría elegido los más desfavorables y odiosos. Un método que permitía condenar no importa que pueblo o episodio histórico, pero la historia no era "un repertorio de pormenores, sino el deposito de grandes resultados" y, en el caso concreto de Hidalgo, el objeto había sido "justo y santo", poco importaba que los medios hubiesen sido "los que permitió la necesidad” (Tornel, 1849d: 2). En resumen, "para lograr la independencia, que es el sumo de los bienes, era preciso arrostrar con la guerra civil, que es el sumo de los males" (Tornel, 1849e: 1). La estrategia es completamente distinta de la utilizada por El Monitor Republicano, y mucho más eficaz. No se

\footnotetext{
3 El director-editor era un español, Rafael Rafael, lo mismo que algunos de sus redactores. Un asunto, el de la continua presencia de españoles en la prensa mexicana del siglo XIX que exigiría un estudio detallado, no sobre quienes fueron, sobre lo que hay estudios bastante detallados (véase, entre otros, María y Campos, 1960; y Mora y Miquel, 2016), sino sobre el significado de su sobrerrepresentación en un campo tan sensible como el de la prensa y la opinión pública.
}

discuten los hechos, era cierto que Hidalgo se había servido de los presos de la cárcel, que algunas de sus primeras víctimas habían sido sus propios amigos y tertulianos, que había mentido y exacerbado los odios para ganarse adeptos y que su catadura moral posiblemente no fuese la más recomendable, sino el contexto en el que se habían producido, aquello que les daba sentido y que podía convertir lo moralmente repudiable en heroico gracias a sus fines. La historia no como una sucesión de detalles sino como el resumen del espíritu de una época.

Todavía al año siguiente, 1850, el orador encargado del discurso conmemorativo del Grito de Dolores en la Alameda de la Ciudad de México consideró necesario referirse a "el escándalo de que en la patria misma de la independencia, se alce una voz que injurie su memoria", pero sin que considerase necesario ya hacer una reivindicación de la figura de Hidalgo. Su gloria y su talla de héroe eran tan evidentes que ni merecía la pena defenderle de este tipo de injurias. Aunque no hubiese proclamado "ningún plan de gobierno, sino únicamente la independencia". Esto era más que suficiente para que los mexicanos le estuviesen eternamente agradecidos. Era un héroe no sólo para México sino también para el mundo y "cuando los intereses de ciertas clases privilegiadas no se sobrepongan a los de la sociedad, nuestra historia será conocida del mundo entero, y el mundo entero hará justicia a Hidalgo" (Castillo Velasco, 1850: 2).

La prensa conservadora, sin embargo, seguirá insistiendo en los años siguientes en la escasa importancia de Hidalgo en el proceso de independencia mexicana y que entre sus planes cuando dio el grito de Dolores estuviesen los de la independencia de la nación "no es concebible que proclamando los derechos de Fernando VII al trono de España, que protestando defenderlos contra la usurpación francesa, se pudiese constituir una nación independiente" (El Correo, 1851a: 1). La sangre derramada por los seguidores de Hidalgo en Granaditas, Guanajuato o el monte de las Cruces no lo había sido por la libertad y la independencia de la nación 
y el saldo de la revolución de Dolores era más que negativo. Podía resumirse en que "había desmoralizado a los pueblos de un modo espantoso, arruinado a nuestra patria y engendrado unos partidos de cuyo maléfico influjo aun nos resentimos" (El Correo, 1852: 1).

El gran problema con Hidalgo, desde la perspectiva conservadora, no era tanto, sin embargo, la falta de un proyecto político articulado como su negación del carácter español de México. Las trágicas consecuencias del imueran los gachupines! que todavía el país estaba pagando. Era el propio ser nacional mexicano el que se había puesto en cuestión en Dolores y eso era más grave que cualquier estrategia política, por errada que fuese. Incluso en aquellos casos en los que se reconoce la importancia del cura de Dolores en la gesta independentista, finalmente no se le podía negar "el mérito de iniciar la cuestión, y de iniciarla con arrojo [...]. Condenar los medios [...] no es condenar la causa" (Esteva, 1853: 1), se insistirá una y otra vez en las consecuencias negativas que para los primeros insurgentes y para su causa había tenido el grito de muerte a los gachupines, que no significaba otra cosa que muerte "a los conquistadores y fundadores de la colonia" a "los padres y abuelos de los que formaban la clase más influyente de la población nativa" (1). Había sido este grito la causa, justificada, del fracaso insurgente.

La revolución se reprimió, pues, por dos causas: la primera, porque renegó del pueblo que formó nuestro pueblo; porque renegó de nuestros padres; porque renegó de la España antigua, cuando la antigua y la nueva España se amaban, como se ama el cuerpo al alma (Esteva, 1851: 1).

La revolución había fracasado porque los mismos mexicanos "los hijos de los conquistadores" se alistaron en el bando de los realistas. Si el México del momento de la Independencia se componía de dos grupos étnicos, los descendientes de los conquistadores y los descendientes de los conquistados, el error del grito de Dolores, con su muerte a los gachupines, había sido el atizar una sangrienta y terrible guerra de castas, ya que "gritando muerte a los españoles europeos, gritaba también muerte para los españoles americanos, que eran sus hijos" (Esteva, 1853: 1).

La respuesta de los liberales será, no sólo reafirmar la importancia de Hidalgo como padre de la independencia sino, sobre todo, convertirle además en el padre de la revolución. El Grito de Dolores habría sido una llamada a la patria para liberarla de la ocupación extranjera y una llamada al pueblo para liberarle de la opresión de los poderosos, tan importante la una como la otra. Como afirmó el Nigromante en su famoso discurso del 16 de septiembre de 1861, aquel que según Altamirano la juventud mexicana leía y aprendía de memoria en la escuela:

Hidalgo en la aurora del 16 de septiembre de 1810 arrojó el guante no solamente a los españoles, sino a la nobleza, al clero, a todas las autoridades, a todas las clases, a todas las razas, a todos los individuos que pudieran tener la pretensión de colocarse más arriba de la soberanía popular (Ramírez, 1861: 1).

Hidalgo era mucho más que el padre de la patria, era el redentor de los oprimidos, el héroe de la humanidad frente al que las más grandes figuras históricas quedaban empequeñecidas. El mismo Ignacio Ramírez, en unas frases anteriores a las aquí citadas, no había dudado, en ese estilo grandilocuente que le es propio, "descubra la ciencia de mi patria las momias de cien épocas enterradas por cien diluvios", en compararlo con Moisés, Mahoma y Washington. No parece necesario precisar que para el Nigromante Hidalgo estaba muy por encima de cualquiera de ellos.

La proclamación del Imperio y la llegada de Maximiliano al trono mexicano produjo un cierto desconcierto en las posturas conservadoras respecto a la figura de Hidalgo, por un lado, Maximiliano apuesta, desde el primer momento y sin ningún tipo de ambigüedad, por el reconocimiento del Grito de Dolores como el acto fundacional de la 
nación; por otro, los juaristas reforzaron en sus discursos la imagen de una línea de continuidad entre el enfrentamiento Hidalgo/ realistas juaristas/imperiales. Una retórica demoledora para los partidarios del Imperio y que los defensores del proyecto de nación conservador intentaron desmontar con todas las armas a su alcance.

Ambos factores, la apuesta de Maximiliano y la necesidad de desmontar el discurso liberal, hicieron que en estos años el discurso conservador se volviese claramente favorable a Hidalgo, centrando sus argumentos en demostrar la aberración de una continuidad histórica entre Hidalgo y Juárez dado el posicionamiento de uno y otro frente a la religión. Hidalgo deja de identificarse con el iMueran los gachupines!, que permitía denigrarlo, para hacerlo con el iViva la Virgen de Guadalupe!, que permitía enaltecerlo. Nada tenían en común los cabecillas liberales, "enemigos de Dios y de su Iglesia", con unos insurgentes cuya proclama había sido "que la religión católica, sin tolerancia de ninguna otra, sería siempre la profesión de fe de la nación mexicana". La Independencia había sido inspirada por "la más ardiente fe cristiana" y el odio a las nuevas ideas liberales que amenazaban extenderse desde Europa. El origen del Grito de Dolores había que buscarlo en "la conducta equívoca de algunos altos funcionarios en materias religiosas" que "habían hecho nacer aquel descontento en personas hasta entonces fieles a su legítimo soberano". Era un sarcasmo que los ateos y anticlericales seguidores de Juárez osasen considerarse herederos de un levantamiento cuyo estandarte había sido la Virgen de Guadalupe y a cuyos jefes, Hidalgo y Morelos, si viviesen en el momento actual "hasta sus ropas sacerdotales los habrían despojado" (El Pájaro Verde, 1865a: 2).

Hidalgo ya no es el inepto y sanguinario responsable de una guerra civil sino el sacerdote que había intentado salvar a México en nombre de la religión. Su motivo no había sido el odio a los españoles ni la voluntad de independencia sino el deseo de salvar la religión cristiana. Cuando se enumeran los gritos bajo los que, según el periódico conser- vador se habían movilizados los seguidores de Hidalgo, se citan "iViva la religión! iviva nuestra Madre santísima de Guadalupe! iviva Fernando VII! y imuera el mal gobierno!”. El centro de lo ocurrido en Guadalupe ya no es el iMueran los gachupines! sino el iViva la Virgen de Guadalupe! y, visto desde esta perspectiva, ya no se trataba de Iturbide o Hidalgo sino de Iturbide e Hidalgo. El uno había iniciado la Independencia y el otro la había consumado, ambos protagonistas de un mismo relato.

Los papeles se invierten en el caso de Iturbide. Los liberales tienden a minimizar su importancia, integridad moral y visión política mientras que los conservadores no sólo le erigen en el verdadero artífice de la independencia de la nación sino también en el principal impulsor de un proyecto de nación que de haberse llevado a cabo habría subsanado la mayoría, sino todos, los problemas de México.

El centro del debate sobre él gira en torno al significado exacto del Plan de Iguala, que los sectores liberales tienden a presentar como el resultado de las concesiones hechas a los que se oponían a la independencia, ya fuesen españoles, "que, aunque domiciliados en México, conservaban como por tradición el odio a los conquistados [...] y tanto por estos motivos como porque debían al régimen colonial fortunas inmensas, honores y distinciones aborrecían la independencia de México"; o "mexicanos de nacimiento, pero españoles de corazón, educados por estos, y por decirlo así, habían mamado sus ideas y afecciones". Los once años de lucha habrían mostrado a estos grupos la imposibilidad de mantener el dominio español, por lo que el Plan de Iguala, que "les concedía todo lo que [...] podían prudentemente desear", les había empujado a proclamarse "desde entonces amigos de nuestra independencia” (El Siglo XIX, 1850: 1).

En esta interpretación la figura de Iturbide aparece con una cierta ambigüedad, podía ser tanto el líder clarividente que avizoró la oportunidad de integrar en el proyecto independentista a los sectores más remisos o el traidor a los principios expuestos por Hi- 
dalgo y por los que miles de mexicanos habían derramado su sangre. El hecho de que en la gestación del plan hubiese tenido una participación relevante el mismísimo Matías Monteagudo, realista recalcitrante y uno de los principales apoyos de Gabriel de Yermo en la prisión del virrey Iturrigaray, no era precisamente el mejor aval. El Plan de Iguala como el precedente de todos los posteriores intentos conservadores de instauración de la monarquía en México. En todo caso el instinto del pueblo mexicano le había llevado a despreciar un pacto "que no le obligaba y reasumió en toda su plenitud todos los derechos de los pueblos libres".

Para los conservadores, por el contrario, no había en la valoración de Iturbide y el Plan de Iguala la más mínima sombra de ambigüedad. El controvertido principio de la Unión entre europeos y americanos no había sido ninguna concesión sino el reconocimiento de la necesaria unión con los

padres de nuestra raza y cuya sangre circula por nuestras venas [...] con los que habían civilizado el país, y puestolo en estado de hacerse libre y soberano [...] con los que habían hecho patria suya la nuestra [...] con los que la habían ayudado a quebrantar los lazos que la estrechaban con su antigua metrópoli, y que iban a correr la suerte siempre peligrosa de las innovaciones (El Correo, 1851b: 1).

Iturbide había sido el hombre providencial capaz de presentar la independencia sin el pecado original del odio contra los españoles con el que había nacido en Dolores. La independencia no era el odio a España "era un acontecimiento obligado y consecuente con la historia de todas las naciones". Y aquí aparecía, una y otra vez, la metáfora biológica tan cara al pensamiento conservador, "llega después el día en que las nuevas sociedades se desprenden de su origen, como el hijo se desprende del padre" (Esteva, 1853: 1). La clarividencia de Iturbide le había hecho ver la necesidad de conjugar intereses distintos, de afirmar el carácter católico de la nación mexicana frente a las veleidades anti-eclesiásticas de la propia España y de unir a europeos y americanos. Esa había sido su grandeza y la que le daba un lugar de honor en el panteón mexicano.

Fuera cual fuese el juicio histórico sobre Iturbide había, de todas formas, un hecho incuestionable, el de su participación del lado de los realistas en la guerra de independencia, para los liberales prueba irrefutable, tanto de su ambigüedad, cuando no de su felonía, como de su tardía, y no decisiva, contribución a la causa de la Independencia.

Los conservadores responderán a esto argumentando, por un lado, que todo indicaba que Iturbide había sido partidario de la Independencia desde el principio. Por otro, que tal como había escrito el propio héroe de Iguala en Diseño crítico de la emancipación y libertad en México, publicado en Londres en 1824, si no se había unido a los primeros insurgentes había sido porque consideró que los planes de Hidalgo, mal concebidos y peor planificados, sólo producirían sangre y destrucción. La evolución posterior no habría hecho sino demostrar lo bien fundado de sus apreciaciones, Hidalgo y sus seguidores

desolaron el país; destruyeron las fortunas; radicaron el odio entre europeos y americanos; sacrificaron millares de víctimas; obstruyeron las fuentes de riqueza; desorganizaron el ejército; aniquilaron la industria; hicieron de peor condición la suerte de los americanos, excitando la vigilancia de los españoles, a vista del peligro que los amenazaba; corrompieron las costumbres, y lejos de conseguir la independencia, aumentaron los obstáculos que a ella se oponían (Diario de Avisos, 1859: 1).

Militar bajo las banderas realistas había sido sencillamente un acto de patriotismo.

\section{A modo de conclusión: el fin de un debate}

Los debates y polémicas sobre el significado de la independencia, continuos y de una gran virulencia discursiva tal como aquí se ha mostrado durante las primeras décadas 
de vida independiente, fueron mucho más que un debate historiográfico. Tuvieron que ver, en primer lugar, con la imaginación de los conflictos bélicos de 1810-1821 como una guerra de independencia y no como una guerra civil y/o una revolución; pero también con el enfrentamiento entre dos proyectos alternativos de nación, legitimados, como casi todo programa identitario, en lecturas divergentes del pasado, del inmediato, guerra de independencia, pero también de los anteriores, épocas virreinal, conquista y época prehispánica. La guerra de Independencia, vista desde esta perspectiva, no era importante sólo por sí misma sino porque en función de cómo se la interpretase cambiaba el sentido y significado de toda la historia anterior y, como consecuencia, de lo que México era y a lo que debía de ser fiel como nación. La Independencia como culminación del proceso iniciado con la Conquista, continuado en la época virreinal y llegado a su pleno desarrollo con la Independencia, versión conservadora; o la independencia como venganza de la conquista, con la resurrección de la nación muerta en 1521, versión liberal. Explica la virulencia de un debate que tenía que ver más con el futuro que con el pasado, con el México que se buscaba construir más que con la historia de lo que había ocurrido, con Hidalgo e Iturbide convertidos en bandera de cada uno de los dos proyectos.

La derrota de Maximiliano marcó el triunfo del proyecto de Estado liberal, que puso fin al conflicto ideológico en torno al que la historiografía ha organizado la vida política del primer México independiente; también el del proyecto de nación liberal, que puso fin a un conflicto identitario al que, sin embargo, esta misma historiografía apenas ha prestado atención. Tan no le ha prestado que ni siquiera disponemos de términos precisos para referirnos a los que militaron en uno y otro campo. El motivo por el que a lo largo de este articulo me he visto obligado a recurrir a los imprecisos, desde el punto de vista identitario, términos de liberales y conservadores, expresión del conflicto sobre derechos y organización social, no del que tiene que ver con qué somos; tampoco por cierto con el que tuvo que ver con el reparto de recursos, en el que el uso de ambos términos resulta al menos igual de poco preciso e inapropiado.

Unos conflictos identitarios que han sido una de las claves de la vida política del mundo contemporáneo y cuya relevancia histórica, en el caso de México, estriba en que mientras el conflicto ideológico, de Estado, se zanjó de manera definitiva con la victoria liberal, ninguno de los regímenes políticos decimonónicos posteriores, ni la República Restaurada ni el Porfiriato, pusieron en cuestión sus principios; el de nación seguiría de alguna manera latente, como una especie de herida abierta y nunca cerrada. Un conflicto en el que la construcción de una memoria compartida sobre la finalmente conocida como guerra de independencia, no guerra civil o revolución, no fue el eje el principal, un lugar ocupado sin ninguna duda por la memoria sobre la conquista, pero sí tuvo un importante protagonismo.

El resultado, una aparentemente inocua guerra de papel sobre el sentido y significado de lo ocurrido entre 1810 y 1821, cuya capacidad de desestabilización y conflicto no puede sin embargo desdeñarse. El debate sobre la historia que es siempre, en última instancia, un debate sobre la memoria.

\section{Fuentes de consulta}

Anievas, José Ignacio (1854), "Discurso patriótico pronunciado en la Alameda de México la mañana del 16 de septiembre de 1854, por el Sr. D. José Ignacio de Anievas", El Siglo XIX, 16 de septiembre, México, p. 1.

Blancarte, Roberto (Comp.) (1994), Cultura e identidad nacional, México, Fondo de Cultura Económica-Conaculta.

Castillo Velasco, José M. (1850), "Oración cívica, pronunciada en la Alameda de México el 16 de septiembre de 1850, aniversario del glorioso grito de Dolores por el ciudadano licenciado José M. del 
Castillo Velasco", El Monitor Republicano, 18 de septiembre, México, pp. 1-3.

Diario de Avisos (1859), "Aniversario de la consumación de nuestra independencia”, 29 de septiembre, México, p. 1.

El Correo (1852), "Editorial. Una cuestión de partido", 18 de marzo, México, p. 1.

El Correo (1851a), "Editorial. La independencia”, 2 de diciembre, México, p. 1.

El Correo (1851b), "Editorial. ¿Cuándo Ilegamos a ser felices?", El Correo, 8 de diciembre, México, p. 1.

El Monitor Republicano (1857), "Editorial. Sentimientos liberales", 4 de noviembre de 1857, México, p. 1.

El Monitor Republicano (1850a), "16 de septiembre. Aniversario de la independencia”, 16 de septiembre, México, pp. 3-4.

El Monitor Republicano (1850b), "Iturbide", 1 de octubre, México, p. 3.

El Monitor Republicano (1849a), "El Universal”, 23 de septiembre, México, pp. 3-4.

El Monitor Republicano (1849b), "Espíritu de la Cámara de Diputados", 25 de septiembre, México, pp. 3-4.

El Ómnibus (1852), "El 16 de septiembre”, 16 de septiembre, México, pp. 1-2.

El Pájaro Verde (1865a), "Los caudillos de 1810”, 16 de septiembre, México, pp. 2-3.

El Pájaro Verde (1865b), "La revolución de Independencia", 27 de septiembre, México, p. 2.

El Sig/O XIX (1851), "La Independencia”, 11 de diciembre de 1851, México, p. 1.

El Siglo XIX (1850), "Revolución moral", 17 de marzo, México, p. 1.

El Universal (1854a), "Editorial. El 16 de Septiembre", 16 de septiembre, México, p. 1.
El Universal (1854b), "Editorial. Entrada del ejército trigarante en la capital", 27 de septiembre, México, p. 1.

El Universal (1849a), "El gran día nacional", 27 de septiembre, México, p. 1.

El Universal (1849b), "Editorial. Grito de Dolores. Vindicación de la historia y de la independencia de México", 23 de noviembre, México, p. 1.

El Universal (1849c), "Editorial. Sobre el discurso del Sr. Director del Colegio de Minería D. José María Tornel, en la distribución de premios de sus alumnos", 24 de noviembre, México, p. 1.

El Universal (1849d), "Grito de Dolores. Vindicación de la historia de la independencia de México", 28 de noviembre, México, p. 1.

El Universal (1849e), "Grito de Dolores. Vindicación de la historia de la independencia de México", 2 de diciembre, México, p. 1.

Esteva, José Ignacio (1853), "Discurso pronunciado en la plaza principal de la heróica ciudad de Veracruz, el día 27 de septiembre de 1853, por el ciudadano consejero del estado José Ignacio Esteva, comisionado al efecto", El Ómnibus, 19 de octubre, México, p. 1.

Fernández Bustamante, Gavino (1845), "Discurso pronunciado por el Sr. Gavino Fernández Bustamante, en la ciudad de San Miguel de Allende, el 16 de Setiembre de 1845", El Monitor Constitucional, 28 de septiembre, México, pp. 3-4.

Garfias, Marcelo (1855), "Discurso pronunciado en el teatro nacional, la noche del 15 de setiembre [sic], por el ciudadano Marcelo Garfias, alumno del nacional Colejio de Letrán" El Monitor Republicano, 5 de octubre, México, pp. 1-2.

Garrido Asperó, María José (2006), Fiestas civicas históricas en la ciudad de México, 1765-1823, México, Instituto Mora. 
González Bocanegra, Francisco (1854), "Discurso leído en el gran teatro de Sana-Anna la noche del 15 de septiembre de 1854 por D. Francisco González Bocanegra, en celebridad del aniversario de la independencia", EI Siglo XIX, 16 de septiembre, México, p. 1.

Hale, Charle A. (1990), "La guerra con Estados Unidos y la crisis del pensamiento mexicano", Secuencia. Revista de historia y ciencias sociales, 16, Ciudad de México, Instituto José María Luis Mora, pp. 43-61.

Herrejón Peredo, Carlos (2000), "La construcción del mito de Hidalgo", en Federico Navarrete y Guilhem Olivier, El héroe entre el mito y la historia, México, UNAM y CEMCA, pp. 235-249.

J.J.C. (1845), "Discurso que en la solemnización del aniversario del glorioso día diez y seis de setiembre, pronuncio en la universidad de esta capital el C. Lic. J.J.C", El Monitor Constitucional, 10 de octubre de 1845, México, p. 1.

María y Campos, Armando de (1960), Reseña histórica del periodismo español en México, México, Compañía Editorial Distribuidora de Ediciones.

Martínez, Miguel (1853), "Discurso cívico en elogio del Excmo. Sr. D. Agustín de Iturbide, pronunciado en Morelia el 27 de Setiembre de 1853 por el Lic. D. Miguel Martínez", El Universal, 10 de octubre de 1853, México, p. 3.

Mora, Pablo y Miquel, Ángel (2008), Españoles en el periodismo mexicano. Siglos XIX y XX, México, UNAM/Universidad Autónoma del Estado de Morelos.

Navarrete, Federico y Guilhem Olivier (2000), El héroe entre el mito y la historia, México, UNAM y CEMCA.

Pérez Vejo, Tomás (2017), “A Historiographical Myth: Spanish Royalists against Insurgent Criollos", en Visoni Alonso, Gilmar; y Jacob, Frank (eds.), Latin America's Martial Age. Conflict and Warfare in the Long Nineteenth Century. Würz- burg, Königshausen \& Neumann, pp. 37-54.

Pérez Vejo, Tomás (2011), "¿Criollos contra criollos? Reflexiones en torno a la historiografía de las independencias", Revista de Occidente, 365, Madrid, Fundación Ortega y Gasset, pp. 7-25.

Pérez Vejo, Tomás (2010), Elegía criolla. Una reinterpretación de las guerras de independencia hispanoamericanas, México, Tusquets Editores.

Prieto, Guillermo (1861), "Discurso pronunciado por el C. Guillermo Prieto, el 17 de Setiembre [sic] de 1861", El Monitor Republicano, 18 de septiembre, pp. 1-2.

Ramírez, Ignacio (1861), "Discurso cívico pronunciado por el C. Lic. Ignacio Ramírez, el 16 de Setiembre de 1861, en la Alameda de México, en memoria de la proclamación de la independencia”, El Monitor Republicano, 17 de septiembre, México, pp. 1-2.

Ranzato, Gabriele (1994), "Un evento antico e un nuovo oggeto di riflessione", en Gabriele Ranzato (editor), Guerre fratricide. Le guerre civili in età contemporanea, Milán, Bollati Boringhieri, pp. IX-LVI.

Rosa, Luis de (1846a), "Discurso pronunciado en la Alameda de esta capital por el ciudadano Luis de la Rosa, en el solemne aniversario de la proclamación de la INDEPENDENCIA nacional, hecha en el pueblo de Dolores por los héroes de la Patria, el 16 de Septiembre de 1810", El Monitor Republicano, 19 de septiembre, México, p. 3.

Rosa, Luis de (1846b), "Discurso pronunciado en la Alameda de esta capital por el ciudadano Luis de la Rosa, en el solemne aniversario de la proclamación de la INDEPENDENCIA nacional, hecha en el pueblos de Dolores por los héroes de la Patria, el 16 de Septiembre de 1810", El Monitor Republicano, 20 de septiembre, México, p. 3. 
Saavedra, Carlos (1850), "Discurso pronunciado en Morelia por el ciudadano Carlos Savedra", El Monitor Republicano, 13 de octubre, México, pp. 1-2.

Suárez Argüello, Ana Rosa (1994), "Una punzante visión de los Estados Unidos (la prensa mexicana después del 47", en Roberto Blancarte (Comp.), Cultura e identidad nacional, México, Fondo de Cultura Económica-CONACULTA, pp. 73-106.

Tornel, José María (1850), "Cuestión histórico-política. Artículos de El Universal", El Monitor Republicano, 4 de enero, México, p. 1.

Tornel, José María (1849a), "El Sr. Alamán", El Universal, 26 de noviembre, México, p.1.

Tornel, José María (1849b), "Cuestión histórico-política", El Monitor Republicano, 3 de diciembre, México, pp. 2-3.

Tornel, José María (1849c), "Artículos sobre El Universal", El Siglo XIX, 12 de diciembre, México, p. 1.

Tornel, José María (1849d), "Cuestión histórico-política. Artículos de El Universal", El Monitor Republicano, 20 de diciembre, México, pp. 1-2.

Tornel, José María (1849e), "Cuestión histórico-política. Artículos de El Universal", El Monitor Republicano, 23 de diciembre, México, p. 1.

Vargas, Eugenio (1859), "Discurso pronunciado el 28 de setiembre de 1859, en la Alameda de Toluca, por el Sr. Secretario de la Comandancia General del Departamento, coronel D. Eugenio Vargas", Diario de Avisos, 16 de octubre, México, p. 1.

Villalobos, Joaquín (1850), "Discurso pronunciado en la función cívica celebrada en el Teatro Nacional la noche del 15 de septiembre, por el joven D. Joaquín Villalobos" El Monitor Republicano, 19 de septiembre, México, pp. 3-4.
Yslas, Gabriel M. (1857), "Oración cívica pronunciada en la Alameda de México el 27 de septiembre de 1857, por el C. Lic. Gabriel M. Yslas, en conmemoración de la entrada del ejército trigarante en la misma ciudad el 27 de septiembre de 1821", El Estandarte Nacional, 28 de septiembre, p. 1.

Recibido: 25 mayo de 2021. Reenviado: 26 de mayo de 2021. Aceptado: 29 junio de 2021.

\section{Tomás Pérez Vejo}

Es doctor en Geografía e Historia por la Universidad Complutense de Madrid. Actualmente es profesor-investigador en el Posgrado en Historia y Etnohistoria (Posgrado de Competencia Internacional) de la Escuela Nacional de Antropología e Historia de México (ENAH-INAH). Es investigador del Sistema Nacional de Investigadores, nivel III. Sus líneas de investigación se inscriben en tres grandes áreas temáticas, dos de conocimiento histórico-Procesos de construcción nacional en lberoamérica. Siglos XIX y XX y Relaciones México-España. Siglos XIX y XX- y una tercera de carácter teórico-metodológico sobre usos políticos de las imágenes. Ha sido profesor invitado en el Consejo Superior de Investigaciones Científicas de España, (CSIC) 2010, École des Hautes Études en Sciences Sociales (EHESS), 2009; Universidad de Cantabria, 2009; El Colegio de México, (2005-2008); Universidad Autónoma del Estado de Morelos, la Universidad de Lyon, 2002-2003. En 2012 fue galardonado por el Estado español con la Encomienda de la Orden de Isabel La Católica y en 2018 por el Estado mexicano con la Orden Mexicana del Águila Azteca. Entre sus más recientes publicaciones destacan Repúblicas urbanas en una Monarquía imperial. Imágenes de ciudades y orden político en la América Virreinal, Bogotá, Crítica (2018) y 3 de julio de 1898, el fin del Imperio español, Madrid, Taurus (2020). 


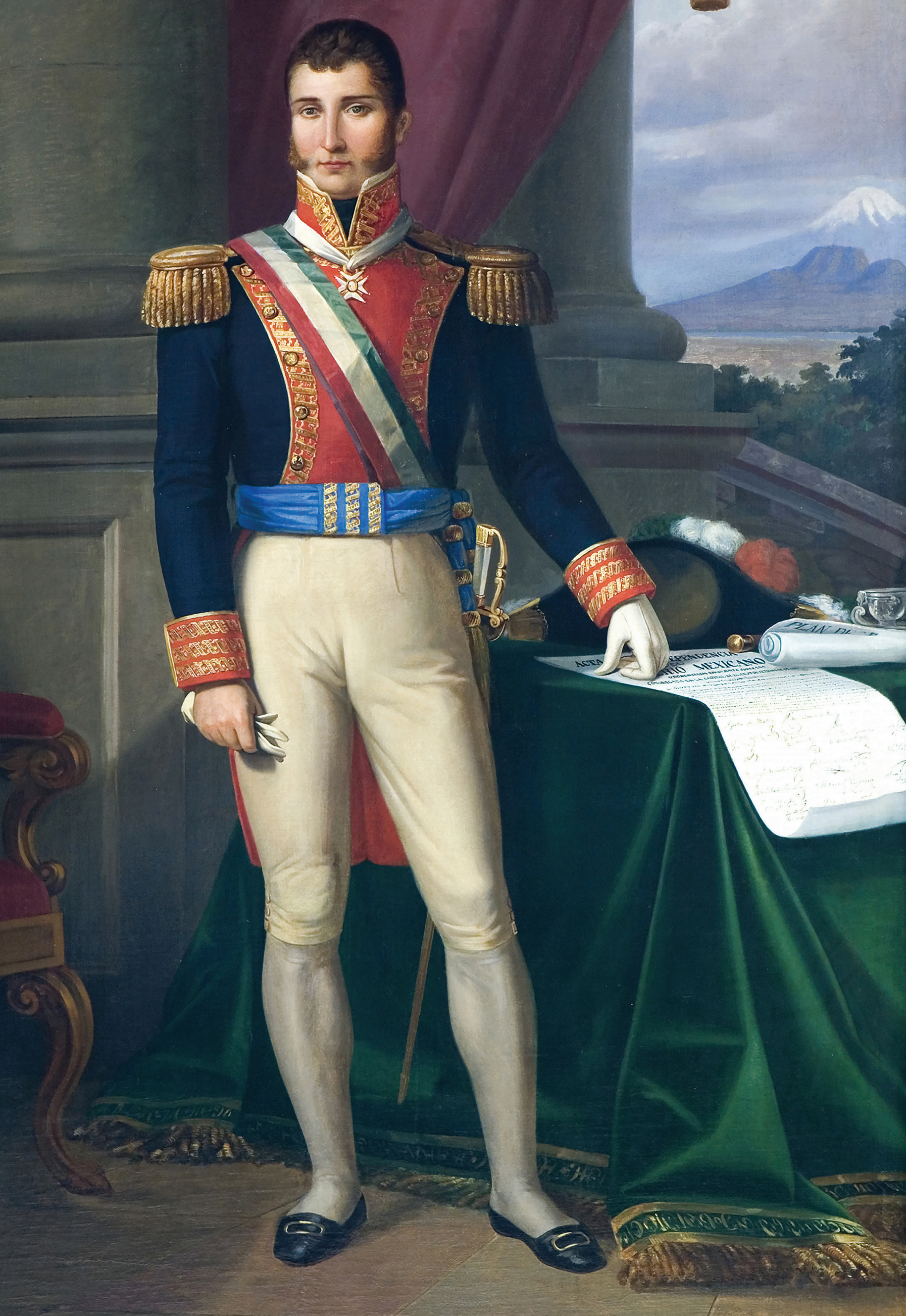

